\title{
Movement and Habitat Use of Headstarted Blanding's Turtles in Michigan
}

\author{
MELISSA D. STARKING-SZYMANSKI, ${ }^{\mathbf{1 , 2}}$ Department of Biology, University of Michigan-Flint, 264 Murchie Science Building, 303 E. \\ Kearsley Street, Flint, MI 48502, USA \\ TERESA YODER-NOWAK, Department of Biology, University of Michigan-Flint, 264 Murchie Science Building, 303 E. Kearsley Street, Flint, \\ MI 48502, USA \\ GREG RYBARCZYK, Department of Geography, Planning, and Environment, University of Michigan-Flint, 516 Murchie Science Building, 303 E. \\ Kearsley Street, Flint, MI 48502, USA \\ HEATHER A. DAWSON, Department of Biology, University of Michigan-Flint, 264 Murchie Science Building, 303 E. Kearsley Street, Flint, MI \\ 48502, USA
}

\begin{abstract}
Captive breeding or headstarting is a management option to increase population numbers in threatened and endangered animals. The success of these programs depends on increasing population numbers while maintaining fitness within populations that contain some captive-reared individuals. As part of an ongoing conservation project with Shiawassee National Wildlife Refuge (SNWR) in Saginaw, Michigan, USA, the Detroit Zoological Society (DZS) headstarted Blanding's turtles (Emydoidea blandingii) to 18 months of age. To determine survival, movements, and habitat use of these headstarted Blanding's turtles, we externally attached radio-transmitters to 24 turtles and released them at 4 sites in release groups of 6 along a transect in a wetland within SNWR during June 2014. We located turtles weekly during the active season (May-Sep) and every 2 weeks during the inactive season (Oct-Apr) for 18 months, starting immediately after release and ending November 2015. We calculated straight-line distances between release sites and home range centers over the study period. We examined habitat use of the turtles in relation to habitat availability. To predict movement of headstarted Blanding's turtles away from release sites, we used geographically weighted regression (GWR) with measured habitat factors and release sites as independent variables. There were differences in home range sizes across release groups but not between years. Headstarted juvenile Blanding's turtles in this study have home range sizes similar to those measured in other studies for wild-hatched juveniles but smaller home ranges than those measured for wild-hatched adults. Our study showed that headstarted Blanding's turtles used habitats with muskrat (Ondatra zibethica) dens and cattails (Typha spp.) more than proportionally available, and used open water, willows (Salix spp.), and lowland forest less than proportionally available. The GWR model was able to predict habitat characteristics (water depth and temperature, duckweed [Lemna minor], cattails, muskrat dens and fields, buttonbush [Cephalanthus occidentalis]) that influenced the movement of turtles away from the release sites. The habitat coefficient's influence on movement varied in relation to the current location of the turtle and as habitat characteristics increased or decreased. Turtle distance from release sites decreased as water depth, water temperature, and duckweed increased, and increased as cattails, muskrat dens and fields, and buttonbush increased. Habitat in the small spatial extent at release sites may affect movement of headstarted Blanding's turtles. Furthermore, this study uses novel methodologies for assessing headstart programs that can aid future conservation and management efforts by providing information on habitat use and movement patterns of headstarted Blanding's turtles after release. (C) 2018 The Wildlife Society.
\end{abstract}

KEY WORDS Blanding's turtle, Emydoidea blandingii, geographically weighted regression, habitat analysis, headstarting, home range, national wildlife refuge, space use, turtle.

Wildlife populations are decreasing across the globe (World Wildlife Fund 2016), and wildlife biologists and managers have attempted to fight this decline. Popular strategies to

Received: 1 May 2018; Accepted: 1 March 2018

${ }^{1}$ E-mail: szyman87@msu.edu

${ }^{2}$ Present address: Department of Fisheries and Wildlife, Michigan State University, Natural Resources Building, 480 Wilson Road, Room 13, East Lansing, MI 48824, USA. prevent the extinction of declining populations include captive breeding, or headstarting (i.e., collecting wild-born young animals and raising them for a certain time to bypass a vulnerable life stage before releasing them into their habitat; Jones and Sievert 2012). However, available research suggests the loss of fitness in captivity can be rapid, its magnitude probably increasing with the duration in captivity (Fraser 2008). Ideally, captive-bred and headstarted individuals maintain wild characteristics (i.e., habitat use and behavior) like wild-born counterparts to avoid 
human-induced changes to the population while increasing population numbers (Mitrus 2008). Thus, part of determining the success of the use of captive breeding or headstarting programs for populations is evaluating what factors increase the survival of captive-reared individuals, and whether survival of captive-reared individuals differ from survival of wild individuals, which may affect fitness within populations that use these programs.

Little research has addressed under what conditions an increase in population abundance due to captive rearing might offset fitness reductions induced in captivity (Fraser 2008). Many herpetofauna conservation programs use headstarting because many members of this group have a type III survivorship curve, characterized by high egg and hatchling mortality rates, with those surviving this stage experiencing longevity (Pearl and Miner 1935, Heppell et al. 1996, Burke et al. 2005). Headstart programs have the potential to increase population numbers of herpetofauna by collecting individuals at the egg or hatchling stage, rearing them in captivity to survive these vulnerable life stages, and then releasing them into the wild.

Analyzing space use after release can help determine success of headstarting programs (Mignet et al. 2014). Comparing the habitat use and movements of headstarted individuals to wild-born counterparts can inform conservationists to differences between the groups (Escobar et al. 2010). By carefully choosing release site locations within the landscape to limit mortality, greater survival of headstarted reptiles is achieved (Reading et al. 2013). Habitat choice by hatchlings and juveniles can result in death if they find themselves in dry uplands that leave them vulnerable to predation (Vander Haegen et al. 2009, Starking-Szymanski 2016). Analyzing space use of surviving headstarted individuals can evaluate whether their home ranges overlap with wild-hatched animals for future reproduction opportunities and propagation of the species, which will inform biologists of the potential success of headstart programs.

A headstarting program at the Shiawassee National Wildlife Refuge (SNWR) for Blanding's turtles (Emydoidea blandingii) has begun to increase abundance of this species of special concern in Michigan, USA. To date, SNWR has received no reports of juvenile wild-born Blanding's turtles despite multiple trapping attempts in the refuge (S. F. Kahl, SNWR, personal communication). Researchers have had difficulty locating juvenile Blanding's turtles and have reported populations skewed towards large, older adults (Ruane et al. 2008); Congdon et al. (1993) has reported a lack of recruitment in Blanding's turtle populations in Michigan. The success of the headstarting program at SNWR depends on high survivability of headstarted individuals during captive rearing and the fitness of headstarted individuals once released into the wild.

We monitored the survival and space use of headstarted Blanding's turtles in the SNWR over 18 months to quantify the relationship between survival and habitat factors for these individuals. First, we hypothesized that headstarted Blanding's turtles would have higher survival rates when released in locations with preferred habitat characteristics. Second, we hypothesized that microhabitat characteristics within a preferred land cover type (emergent wetlands) would influence headstarted Blanding's turtles movements away from release site. In addition, we determined home ranges for these headstarted individuals to compare them with habitat use of wild-born individuals from other studies.

\section{STUDY AREA}

The study area for this research was SNWR, Saginaw, Michigan. The SNWR is a 3,885-ha wetland complex that is part of the National Wildlife Refuge System (Fig. 1), is within Michigan's largest watershed, and is centered at the convergence of 4 major rivers. It is part of the larger Saginaw Lowland and varies in elevation 167-212 $\mathrm{m}$ above mean sea level. Refuge staff manage and conserve all native habitats and native species within the refuge. Emergent marshes, shrub marsh, forested wetlands, river flood plains, and forested uplands are some of the most critical land cover types within SNWR for the Blanding's turtle. The United States Fish and Wildlife (USFWS) staff actively manage emergent marsh pools by controlling vegetation and water levels at the refuge (Spencer et al. 2001). The surrounding landscape includes agricultural fields and suburban neighborhoods. The climate of central Michigan is humid continental (Peel et al. 2007), with colder winters (29-yr record mean of $-8^{\circ} \mathrm{C}$ in Jan), mild summers $\left(29-\mathrm{yr}\right.$ record mean of $27^{\circ} \mathrm{C}$ in $\mathrm{Jul}$ ), and averaging $83.8 \mathrm{~cm}$ annual rainfall (Saginaw, MI Weather Station Data). Nesting season occurs May-June; beginning in 2010 SNWR staff and volunteers located adult female Blanding's turtles traversing terrestrial habitats for nesting in SNWR. Our study occurred June 2014 through November 2016. Other species that reside in the refuge include mammals such as raccoons (Procyon lotor) that prey on turtle eggs and hatchlings within the SNWR (S. F. Kahl, personal communication), amphibians (e.g., leopard frogs [Lithobates pipiens]), many types of reptiles including the Blanding's turtle, and many wading birds that use the refuge as a migration stopover or summer residence (e.g., great blue heron [Ardea herodias]).

\section{METHODS}

Biologists from SNWR and the Detroit Zoological Society (DZS) transported adult females (determined to be gravid via palpitation) to the DZS's facility and $\mathrm{x}$-rayed them for egg enumeration. These gravid females received an injection of oxytocin (10 U/kg intramuscular) from DZS veterinarians to induce oviposition. A second injection of oxytocin was administered at the same dosage if oviposition did not occur within 2 hours. After ovipositing, refuge staff or volunteers released the adult females at their collection site in SNWR. Staff from the DZS incubated the Blanding's turtle eggs laid by these females to attempt to produce a 30:70 male to female ratio using temperature-dependent sex determination that occurs in turtles (Gutzke and Packard 1987). To achieve this ratio, incubation of $30 \%$ of the eggs was at $28.3{ }^{\circ} \mathrm{C}$ (males) and incubation of the remaining $70 \%$ was at $30.8^{\circ} \mathrm{C}$ (females; Gutzke and Packard 1987). However, sex of the hatchling Blanding's turtles was not known for certain 


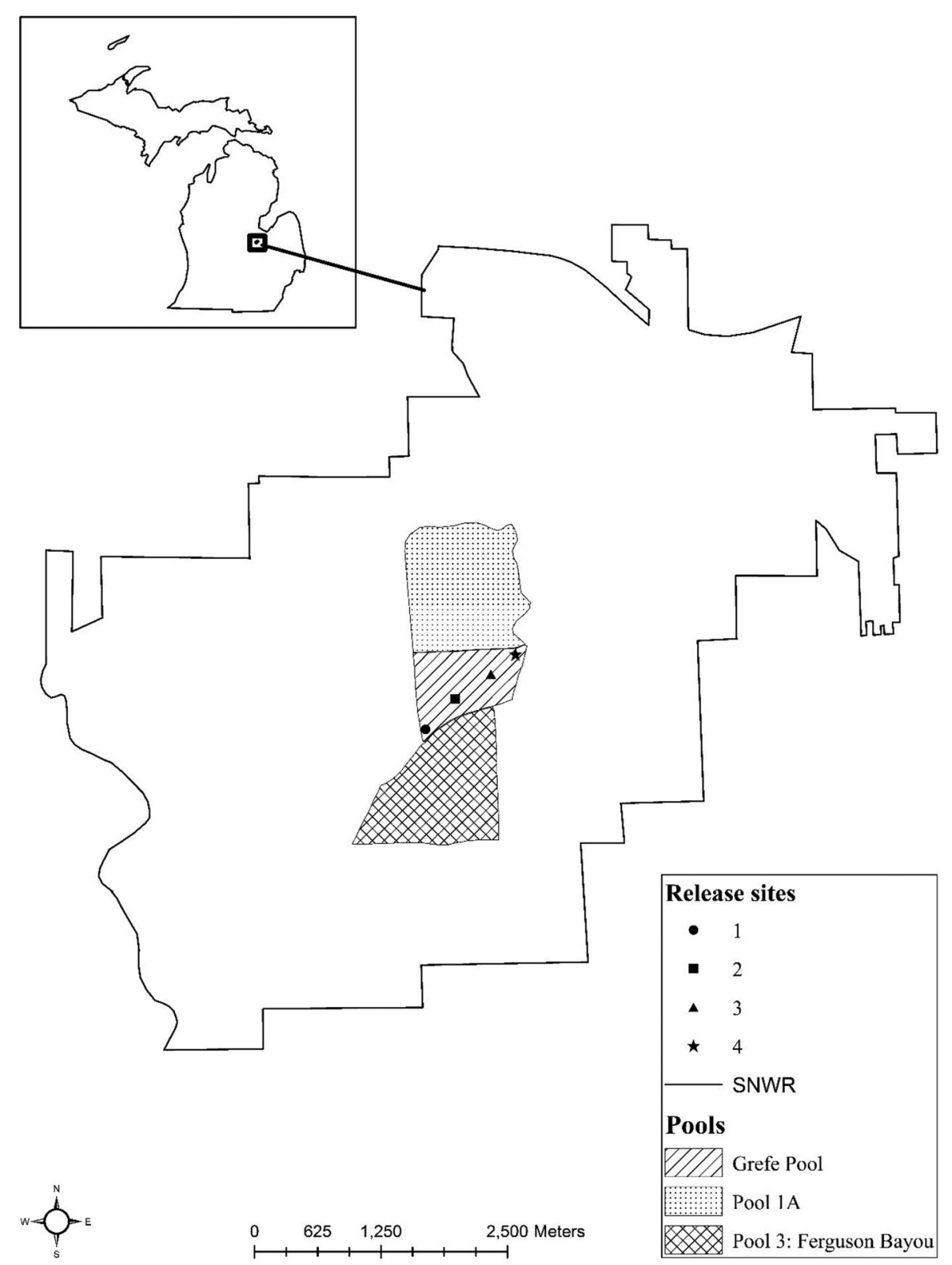

Figure 1. Pools within Shiawassee National Wildlife Refuge (SWNR), Michigan, USA, June 2014 to November, used by Blanding's turtles. Release sites in Grefe Pool are shown. Shiawassee National Wildlife Refuge shown in inset map in Michigan.

because secondary sexual characteristics do not develop until sexual maturity at 14-20 years of age. The DZS staff raised these hatchling Blanding's turtles in captivity at the DZS's facilities until turtles either obtained a carapace length of $10.16 \mathrm{~cm}$, or for a duration of 18 months.

In 2014, DZS staff randomly selected 24 turtles from those that were $>1$ year old and had carapace lengths $>10.16 \mathrm{~cm}$. These 24 turtles received $12-\mathrm{mm}$ passive integrated transponder (PIT) tags $(12.5 \times 2.12 \mathrm{~mm}, 115 \mathrm{mg}$; Biomark, Boise, ID, USA) via injection into the body cavity by DZS veterinarians. We then notched each turtle's carapace (Cagle 1939), and used the PIT tags and carapace notches to identify all 24 turtles individually. We fitted all 24 turtles with R1680 radio transmitters (3.6 g; Advanced Telemetry Systems, Isanti, MN, USA) by attaching the transmitters to the carapace externally using Devcon clear coat epoxy (ITW Polymers Adhesives North America, Danvers, MA, USA) and PC Marine hand moldable all-purpose epoxy putty (Protective Coating Company, Allentown, PA, USA). Beginning mass for all headstarted Blanding's turtles was 91-150 g. We fitted the 8 turtles with the lowest added percent mass from transmitters $(2-5 \% \mathrm{~g})$ with Thermochron iButtons ( $3.3 \mathrm{~g}$; iButtonLink, Whitewater, WI, USA) attached to the carapace with the same 2 previously mentioned epoxies for a concurrent study on thermoregulation. We kept total mass of transmitters, iButtons, and epoxies at $<10 \%$ of each turtle's body mass to avoid negative effects on movement and survival on the headstarted turtles. Although this is higher than the $5 \%$ recommended in the most recent studies, Forsythe et al. (2004) added tracking 
devices that weighed up to $13 \%$ on eastern box turtles (Terrapene carolina carolina) with no ill effects. We recaptured turtles in fall 2014, spring 2015, and fall 2015 to remove and replace the transmitters or iButtons. We completed this research in accordance with University Committee for the Use and Care of Animals from the University of Michigan-Flint (protocol numbers PRO00006431, PRO00003978, PRO00005752). This research complied with all applicable state of Michigan land use and scientific collection permits issued by the Michigan Department of Natural Resources and in accordance with the USFWS from SNWR.

Based on geographic information system (GIS) analysis of a previous study on adult Blanding's turtles in Michigan, and in consultation with USFWS biologists from SNWR, we chose Grefe pool as the release location for the headstarted turtles (Congdon et al. 1993, 2011; Fig. 1). On 17 June 2014, we chose the 24 turtles at random to be released at 1 of 4 release sites ( $n=6$ at each site) evenly spaced along a transect in Grefe pool (Fig. 1). The different microhabitat conditions at the point of turtle release were open water (site 1), sparse cattails $(<25 \%$ cattails within a $1-\mathrm{m}$ quadrant $)$ with duckweed (site 2), willows with duckweed (site 3), and dense cattails (100\% cattails within a 1 -m quadrant, site 4$)$.

We tracked turtles from June 2014 through November 2015, approximately once/week during the active seasons (May-Sep) and once every other week during the inactive season (Oct-Apr). We determined survival by monitoring turtle movements; if an individual had not moved for $>3$ tracking events then we located the turtle and visually assessed if mortality had occurred. After we located a turtle via radio-telemetry, we placed a $1-\mathrm{m}^{2}$ floating quadrat with the turtle approximately in the center and recorded global positioning system coordinates using a Trimble field computer (GeoExplorer 6000 series, Trimble Navigation Limited, Sunnyvale, CA, USA). The habitat factors we recorded within the quadrant were water depth, ice thickness (when applicable), substrate depth, water temperature, air temperature, above water vegetation type, and vegetation dominance. We measured water depth using a Keson metric tape with a Hayward fishing weight $(2.72 \mathrm{~kg})$ attached. We measured ice thickness with a clear metric ruler. We measured substrate depth by placing the Hayward fishing weight $(2.72 \mathrm{~kg})$ on the end of the Keson Metric measuring tape and measuring how far the weight sank into the substrate once released. We identified emergent vegetation and estimated dominant of vegetation using methods similar to Millar and Blouin-Demers (2011): 0\% vegetation, 25\% vegetation, $50 \%$ vegetation, $75 \%$ vegetation, or $100 \%$ vegetation. We recorded air and surface water temperature at each turtle relocation with a liquid-in-glass field thermometer with a temperature range $-30{ }^{\circ} \mathrm{C}$ to $50^{\circ} \mathrm{C}$ (Weksler Glass Thermometer, Charlottesville, VA, USA). We used the GIS software ArcMap (version 10.3, Environmental Systems Research Institute, Redlands, CA, USA) to create maps of turtle locations, identify homes ranges (ha) of individual turtles using the minimum bounding geometry tool, and determine movement patterns by turtles. We performed additional statistics using $\mathrm{R}$, packages base, lme4, and sjstats (Bates et al. 2015, R Core Team 2016, Lüdecke 2018).

To calculate the distances moved by each turtle between relocations, we calculated straight-line distances (m) between each turtle point in sequential order. We found mean daily movement pattern distances by dividing the distance between relocations by the number of days between each tracking and relocation event. Although this is an underestimation of movement, previous studies reported this to be a viable way to compare distances moved between animals (Millspaugh and Marzluff 2001, Millar and BlouinDemers 2011, Jaeger and Cobb 2012, Anthonysamy et al. 2013). We used mixed effects models to analyze cumulative straight-line distances between years and release groups with turtle as a random effect and calculated confidence intervals for the intercepts to reveal a positive or negative biological effect by checking for an overlap of zero (Bates et al. 2015, Lüdecke 2018). If confidence intervals did not overlap zero, we used the Cohens $f^{2}$ effect sizes to derive biological relevance, with Cohen's $f^{2}$ local effect sizes measured as small $\left(f^{2} \geq 0.02\right)$, medium $\left(f^{2} \geq 0.15\right)$, and large effects $\left(f^{2} \geq 0.35\right.$; Cohen 1988).

We calculated minimum convex polygon (MCP) home ranges (ha) in ArcMap. We used mixed effects models to analyze home range area (ha) between years and release groups with pairwise $t$-tests to show mean differences and calculated confidence intervals for the intercepts and Cohens $f^{2}$ effect sizes for models (Bates et al. 2015, Lüdecke 2018). We calculated the center for each home range and measured the distance to the release sites.

We constructed a population range (ha) using the MCP method in ArcMap, similar to the home ranges by creating an MCP around the location points of all of the 24 turtles. We used orthophotos, satellite imagery, and ground truthing to create land cover polygons within ArcMap, and measured the area of each land cover type to determine availability within the population range. Aerial orthophotographs collected and incorporated into a GIS is an approach for carrying out visual and spatial analysis of Blanding's turtles and their habitat (Maktav et al. 2000, Barker and King 2012). We relocated turtles in and around muskrat (Ondatra zibethica) dens frequently, which led us to calculate the area of muskrat dens in ArcMap by placing a circular polygon with a diameter of $1 \mathrm{~m}$ around each den point location recorded in the field or obtained via orthophotos taken in 2014. We used chi-square goodness-of-fit tests with Bonferroni $z$-stat confidence intervals to determine if observed habitat use differed from expected habitat use (Neu et al. 1974, Byers et al. 1984). This test detects selectivity of resources by animals (Alldredge and Griswold 2006).

To test our hypothesis that microhabitat characteristics would influence headstarted Blanding's turtles movements away from release site, we conducted global (i.e., ordinary least squares [OLS]) and spatial regression (i.e., geographically weighted regression [GWR]) analyses. We did this to visualize and explore how habitat variables influenced the 
distance turtles traveled away from their release sites (i.e., the dependent variable). We predict that turtles released in a preferred cover type (e.g., cattails) will move shorter distances than turtles released in non-preferred cover types (e.g., open water). The OLS served as a base model in this study; we chose the GWR model as the primary model because it accounts for spatial effects (i.e., spatial autocorrelation; Fotheringham et al. 1998, 2000; McNew et al. 2013) and has been used in previous biological modeling research (Kimsey et al. 2008). We used ArcMap for all regression analyses (i.e., OLS and GWR). The explanatory factors considered were the microhabitat factors collected at each turtle location and the release groups. Microhabitat factors initially consisted of 14 factors, including water depth $(\mathrm{cm})$, water temperature $\left({ }^{\circ} \mathrm{C}\right)$, substrate depth $(\mathrm{cm})$, air temperature $\left({ }^{\circ} \mathrm{C}\right)$, proportion of cover for duckweed, other floating vegetation, cattails up, cattails down (muskrat dens, push-ups, and fields), willow, grass, log, grapevine, buttonbush, and ice $(\mathrm{mm})$. We used dummy variables for the 4 release groups. We assessed possible model correlates using exploratory global regression analysis in ArcGIS. We added all possible independent variables simultaneously to the model. The procedure resulted in traditional measures of model robustness metrics: adjusted $R^{2}$, corrected Akaike's Information Criterion $\left(\mathrm{AIC}_{c}\right)$, variance inflation factor (VIF), and OLS model $t$-test $P$-values $(P<0.05)$. We calculated model estimates, confidence intervals, and Cohen's $f^{2}$ effect sizes to determine the best independent variables for explaining turtle travel distance. Variables best explaining turtle travel distance were those with confidence intervals not overlapping zero, thus revealing a positive or negative biological effect.

We developed the OLS model to examine universal relations between turtle distance from release sites and the selected independent variables. This traditional approach is a baseline model because it assumes spatial stationarity among selected variables. After we developed the OLS model, we tested the standardized residuals for autocorrelation using global Moran's $I$ index in ArcGIS software. The metric is frequently used to test for spatial autocorrelation (Rosenshein and Scott 2011) and has been used in past ecological studies (Dormann et al. 2007). The index produces 1 statistic for each variable and ranges from -1 to 1 . Positive values indicate positive spatial autocorrelation and negative values highlight an inverse spatial relationship (Burt et al. 2009). We built off these outputs to create a spatially explicit GWR model.

Because spatial autocorrelation is a known factor when assessing environmental and biological relationships (Legendre 1993), we accounted for it by constructing a GWR model in ArcGIS software using the same variables as in the best fit OLS model. The GWR model is a local model because it applies a regression equation to each sample (Charlton and Fotheringham 2009, Fotheringham 2009). Moreover, the mathematical expression for GWR is similar to the OLS in that local parameters take the place of global parameters (Fotheringham et al. 2002). Also engrained in this model is the accountability of distance. The equation allows for a spatial shift in parameters based on local influences, which results in a better fitting model. We used $\mathrm{AIC}_{c}$ to assess the strength of the model, with a lower $\mathrm{AIC}_{c}$ indicating a better fit, and compared it to the OLS output.

The GWR equation can be expressed as:

$$
y_{i}=\beta_{0}\left(u_{i}, v_{i}\right)+\sum_{k}^{p} \beta_{k}\left(u_{i}, v_{i}\right) x_{i k}+\epsilon_{i}
$$

where $y_{i}$ is the dependent variable (distance to release site) at location $i, \beta_{0}\left(u_{i}, v_{i}\right)$ is the intercept at location $i, \beta_{k}\left(u_{i}, v_{i}\right)$ is the estimated $k$ th parameter at location $i, x_{i k}$ is the independent variable of the $k$ th parameter at location $i$, and $\epsilon_{i}$ is the error term at location $i$. The GWR model assumes that the error term is independent and identically distributed (Zhao and Park 2004).

\section{RESULTS}

We collected 899 data points on 24 headstarted Blanding's turtles. All 24 turtles survived through spring 2015, past their first hibernation. During the 2015 tracking season, researchers were unable to locate 8 turtles: 5 turtle transmitters were shed with scutes, researchers lost signals for 2 turtle transmitters, and 1 transmitter signal stopped moving under a muskrat den because the turtle died or shed its transmitter. One confirmed death from predation occurred where a turtle was located in a vernal pool that dried during summer 2015. We found mammal teeth marks on the transmitter and turtle's carapace. The overall survival of the headstarted Blanding's turtles released in SNWR was 63-96\%. The best-case survival estimate (96\%) assumes that every turtle except for the one that was confirmed dead survived, and those who were not located simply lost their transmitters $(n=8)$ when their scutes shed in the spring or summer the year after release. The worst-case survival estimate (63\%) assumes that every turtle that was not located died, and that only turtles that we tracked until the end of the study survived. The best-case survival estimates were $83 \%$, $100 \%, 100 \%$, and $100 \%$ for release groups $1-4$, respectively. The worst-case survival estimates were $33 \%, 100 \%, 67 \%$, and $50 \%$ for release groups $1-4$, respectively. We tracked the initial 24 turtles for 310 days and tracked the remaining 15 turtles an additional 205 days (length of the study was 515 days).

The mean daily movement for the headstarted Blanding's turtles was $26.38 \mathrm{~m}$. The mean cumulative straight-line movement distance for the headstarted Blanding's turtles over the course of the study was $1,005.0 \pm 511.6 \mathrm{~m}$ (SD). The cumulative mean straight-line movement for 2014 was $476.4 \pm 280.0 \mathrm{~m}$ and for 2015 was $513.0 \pm 368.3 \mathrm{~m}$ (Fig. 2). The model with individual turtle as a random effect indicated individual turtles did not affect straight-line movements. There was no effect of year $\left(F_{1,40}=0.156,95 \% \mathrm{CI}=\right.$ -153.54-226.61) when comparing mean cumulative straight-line distances between release groups. Mean cumulative straight-line movements did not differ among release groups $\left(F_{3,20}=3.850,95 \% \mathrm{CI}=-345.601-20.769\right)$. Additionally, the interaction between year and release group showed no difference in mean cumulative 


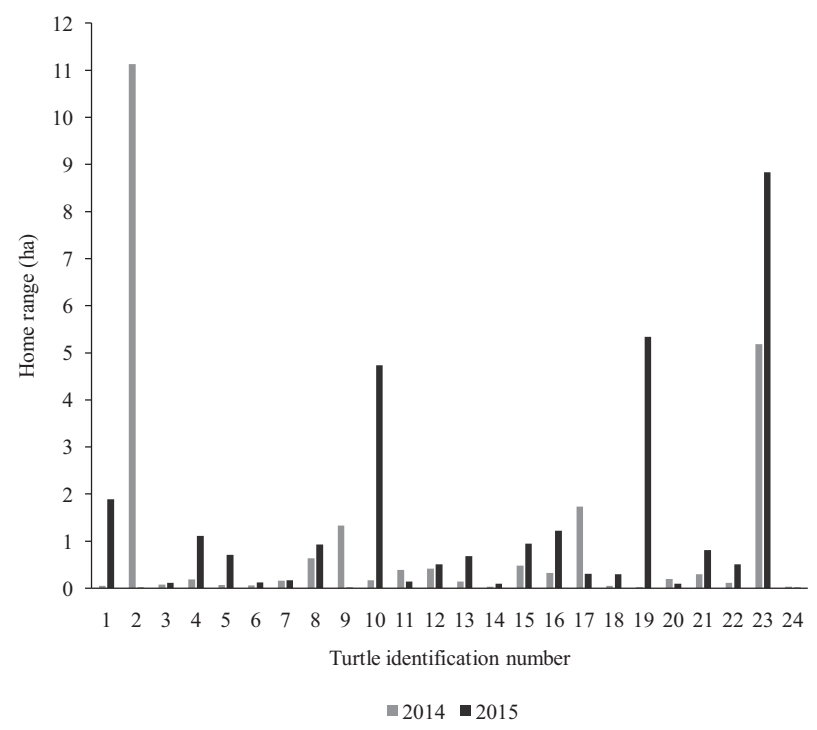

Figure 3. Area (ha) of minimum convex polygon home ranges for 2014 and 2015 for each headstarted Blanding's turtle in Shiawassee National Wildlife Refuge, Michigan, USA.

straight-line movement by turtles $\left(F_{3,20}=0.046,95 \%\right.$ $\mathrm{CI}=-184.49-149.13$ ).

The total mean MCP home range area for the headstarted Blanding's turtles over the course of the study was $2.80 \pm 0.95$ ha (Fig. 3). The mean home range for 2014 was $0.97 \pm 2.4 \mathrm{ha}$ and for 2015 was $1.2 \pm 2.1 \mathrm{ha}$. Turtle home range area for the first year (2014) and the second year (2015) were not different (Fig. 3; $F_{1,20}=0.179,95 \% \mathrm{CI}=-1.06-$ 1.58). Home range size was different among release groups $\left(F_{3,}, 20=4.808, \quad 95 \% \quad \mathrm{CI}=-33,733.76\right.$ to -939.19 , $\left.f^{2}=0.467\right)$. Turtles from release group $1(\bar{x}=2.9 \pm 3.9)$ had a mean home range area 3.7 times larger than turtles in release group $2(\bar{x}=0.61 \pm 1.3), 4.6$ times larger than release group $3(\bar{x}=0.51 \pm 0.37)$, and 5.6 times larger than release group $4(\bar{x}=0.43 \pm 0.56)$. The distance from release site to center home range for all turtles was $184.81 \pm 129.60 \mathrm{~m}$ (Table 1). Distance between release sites and home range centers did not differ across release groups $\left(F_{3,20}=4.100\right.$, 95\% CI $=-91.04-1.09$, Table 1).

We compared habitat use to availability for 6 land cover types (willows, floating vegetation, open water, lowland forest, muskrat den, cattails) within the headstarted Blanding's turtle population MCP range $\left(\chi_{5}^{2}=46,854.06\right.$, $n=24, P \leq 0.001$; Fig. 4). Out of the 6 land cover types, turtles used open water, lowland forested wetlands, and willows less than their availability, used floating aquatic vegetation in proportion to its availability, and used cattails and muskrat dens more than their availability (Table 2).

We used the highest-ranking OLS model to choose our list of independent variables. We found all positively clustered independent variables in the OLS model indicating spatial autocorrelation. The habitat variables in the model were water depth, water temperature, duckweed, cattails, muskrat dens (including muskrat disturbed areas with cut down cattails termed muskrat fields), buttonbushes, and release

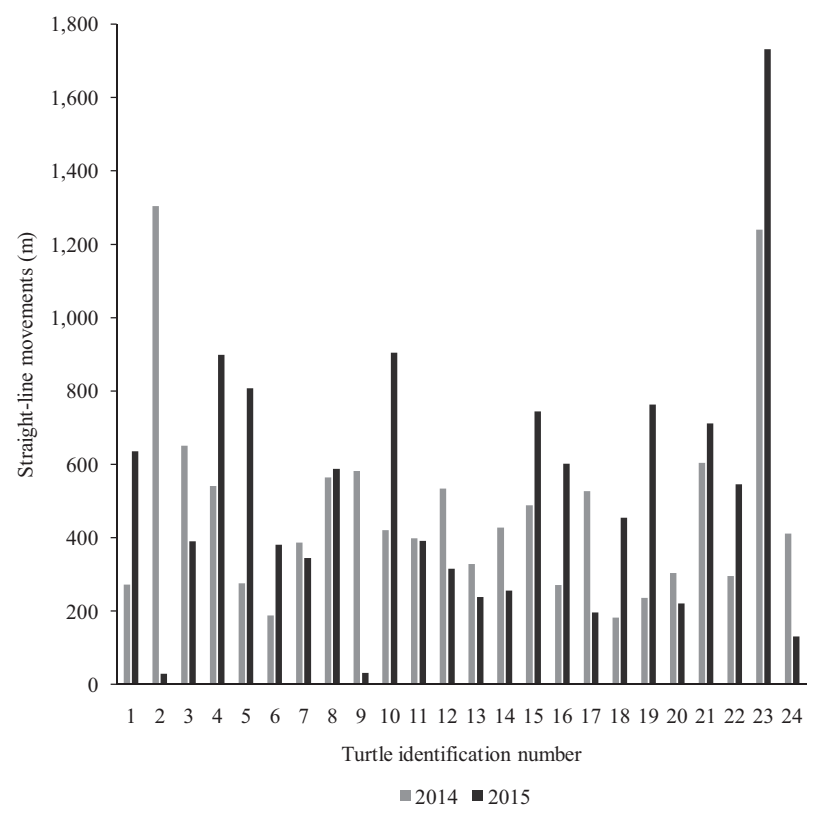

Figure 2. Straight-line distances $(\mathrm{m})$ between relocations (weekly Apr-Oct, biweekly Nov-Mar) that each headstarted Blanding's turtle moved for 2014 and 2015 in Shiawassee National Wildlife Refuge, Michigan, USA.

groups. The OLS results indicated an adjusted $R^{2}$ value of 0.335. All VIF values were 1.1-1.8, which is below the recommended 7.5 indicating there is no redundancy in explanatory variables.

The GWR model showed marked increase in robustness compared to the OLS model, and several independent variables were related to turtle travel distance (Table 3 and Fig. 5). The GWR adjusted $R^{2}$ was 0.755 , which was greater than the OLS model (adjusted $R^{2}=0.329$ ). The $\mathrm{AIC}_{c}$ for the GWR model was 897.07 units lower than the OLS model $\mathrm{AIC}_{c}$, indicating that the GWR model was a better fit. The GWR model results indicate that as turtles moved away from their release sites, the habitat factors encountered would influence the distance turtles moved; if habitat factors with negative coefficients were encountered turtles would continue to move, meanwhile the opposite would happen for habitat factors with positive coefficients. Cohen's $f^{2}$ local effect size from the model indicated water depth and release group had the greatest effect on the distance turtles moved from release sites (Table 3). In the GWR model, turtles released in open water (release group 1) moved the greatest distance from their release site, while turtles released in dense cattails (release group 4) moved the least distance from their

Table 1. Mean distance and standard deviation $(\mathrm{m})$ between home range center and release site for each release site for headstarted Blanding's turtles at Shiawassee National Wildlife Refuge, Michigan, USA, June 2014 to November 2015.

\begin{tabular}{lcc}
\hline Release site & Distance & SD \\
\hline 1 (open water) & 371 & 254 \\
2 (sparse cattails) & 148 & 133 \\
3 (willows) & 213 & 68 \\
4 (dense cattails) & 150 & 141 \\
$\bar{x}$ & 185 & 130 \\
\hline
\end{tabular}




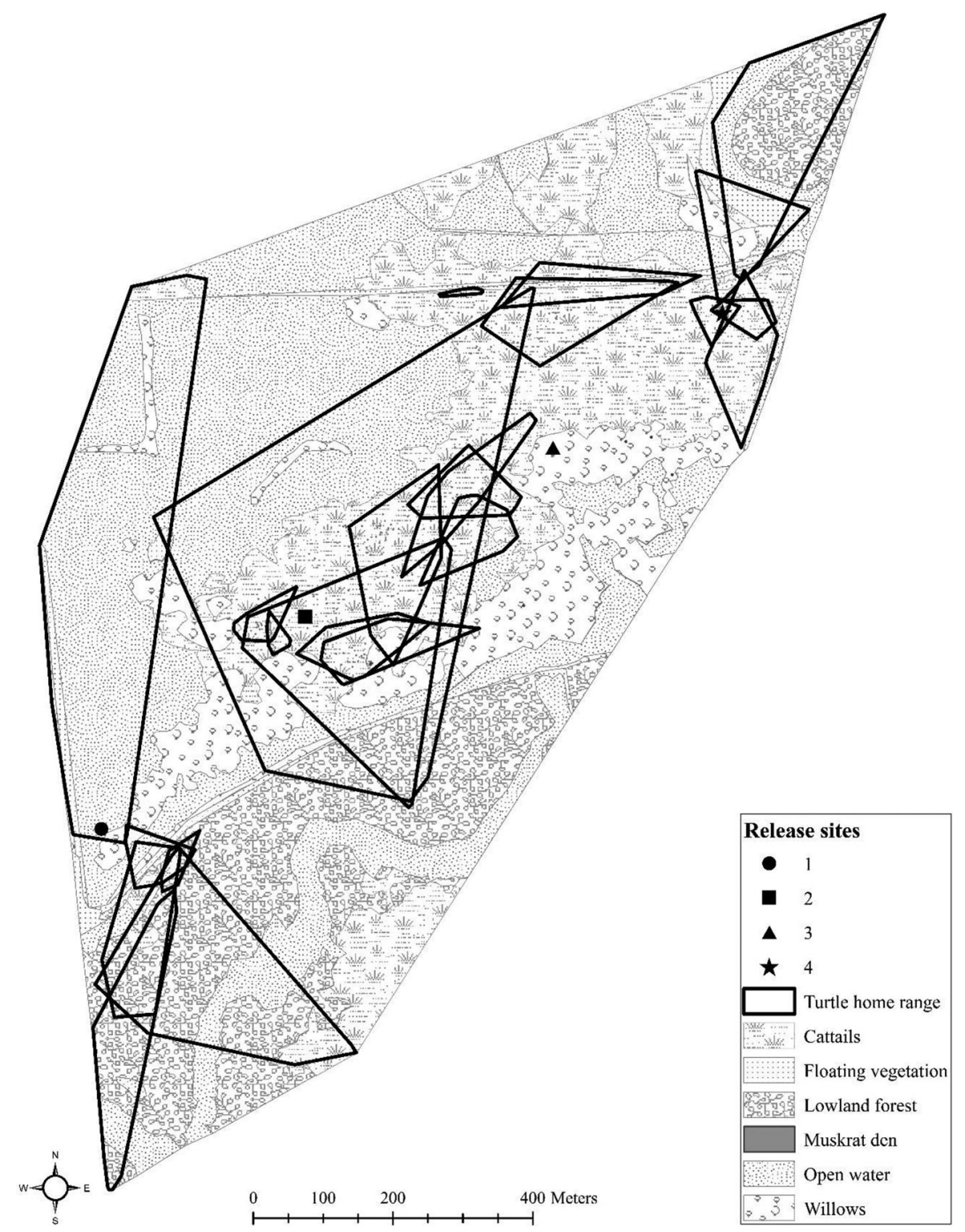

Figure 4. Minimum convex polygon home ranges of 24 headstarted Blanding's turtles in Shiawassee National Wildlife Refuge, Michigan, USA, June 2014 to November 2015 over 18 months. Home ranges are in black. Available land cover types are shown within the population range with release sites of the turtles.

release site (Table 3). Turtles moved farther from their release sites as they encountered increased water depth, temperature, and duckweed (Table 3). Turtles moved shorter distances from their release sites once they encountered cattails, muskrat down cattails, and buttonbushes. Thus, headstarted Blanding's turtle's home range area was larger when released in non-preferred habitat as turtles moved farther from the release site, and turtles had smaller home range areas when released in preferred habitat as turtle movements remained closer to the release site.

Table 2. Habitat availability versus use chi-square goodness-of-fit test results with Bonferroni $z$-stat confidence intervals for headstarted Blanding's turtles at Shiawassee National Wildlife Refuge, Michigan, USA, June 2014 to November 2015. We show the $95 \%$ confidence intervals around proportion of habitat use (observed) compared to habitat available for the headstarted Blanding's turtles.

\begin{tabular}{|c|c|c|c|c|}
\hline $\begin{array}{l}\text { Habitat } \\
\text { variable }\end{array}$ & $\begin{array}{c}\text { Proportion of area } \\
\text { available }\end{array}$ & $\begin{array}{c}\text { Habitat use compared to } \\
\text { available }\end{array}$ & $\begin{array}{c}\text { Number of relocations } \\
\text { observed }\end{array}$ & $\begin{array}{c}\text { Bonferroni } z \text {-stat CI on proportion of } \\
\text { observed }\end{array}$ \\
\hline Open water & 0.395 & Less & 4 & -0.001 to 0.010 \\
\hline Cattails & 0.270 & More & 489 & 0.501 to 0.587 \\
\hline $\begin{array}{l}\text { Lowland } \\
\text { forest }\end{array}$ & 0.190 & Less & 132 & 0.117 to 0.178 \\
\hline Willows & 0.119 & Less & 20 & 0.009 to 0.035 \\
\hline $\begin{array}{l}\text { Floating } \\
\text { aquatic }\end{array}$ & 0.025 & In proportion & 16 & 0.006 to 0.029 \\
\hline Muskrat dens & 0.001 & More & 238 & 0.226 to 0.302 \\
\hline
\end{tabular}


Table 3. Geographically weighted regression analysis of distance moved from release sites for headstarted Blanding's turtles at Shiawassee National Wildlife Refuge, Michigan, USA, June 2014 to November 2015. For each independent variable, we present the variance inflation factor (VIF), mean geographically weighted regression model coeffecient, confidence interval, and Cohen's $f^{2}$ effect sizes (small $=f^{2} \geq 0.02$, medium $=f^{2} \geq 0.15$, and large $=f^{2} \geq 0.35$ effects; Cohen 1988).

\begin{tabular}{lcccc}
\hline Habitat variables & VIF & Mean coefficient & 95\% CI & Cohen's $\boldsymbol{f}^{\mathbf{2}}$ \\
\hline Water depth $(\mathrm{cm})^{\text {Water temp }\left(\mathrm{C}^{\circ}\right)}$ & 1.791 & -0.737 & -0.786 to -0.688 & 0.343 \\
Duckweed $^{\mathrm{a}}$ & 1.330 & -0.257 & -0.308 to -0.205 & 0.076 \\
Cattails $^{\mathrm{a}}$ & 1.531 & -0.272 & -0.287 to -0.256 & 0.149 to 0.196 \\
Muskrat down cattails $^{\mathrm{a}}$ & 1.398 & 0.173 & 0.331 to 0.368 & 0.116 \\
Buttonbush $^{\mathrm{a}}$ & 1.723 & 0.350 & 1.044 to 1.350 & 0.051 \\
Release group 3 $^{\mathrm{b}}$ & 1.145 & 1.197 & 124.703 to 129.603 & 0.124 \\
Release group 2 & 1.233 & 127.153 & 137.422 to 160.597 & 0.267 \\
Release group 1 $^{\mathrm{b}}$ & 1.339 & 149.010 & 378.007 to 406.226 & 0.430 \\
\hline
\end{tabular}

${ }^{a}$ Proportion measured in quadrant at turtle relocations.

${ }^{\mathrm{b}}$ Dummy variables (reference is release group 4).

\section{DISCUSSION}

Three main conclusions emerged from this research. First, survivorship of headstarted turtles was high (100\% the first year and $63-96 \%$ the second year). Second, headstarted Blanding's turtles behaved similarly to their wild-born counterparts. The home range comparisons from other studies support this conclusion (Table 4). Third, we found microhabitat use to be an important predictor of movement distance of headstarted Blanding's turtles, and differences in release site habitat contributed to the variation in movement behavior. Because of the high survivorship and similar movement behavior to wild-born hatchlings, we believe that thus far, the headstart program at SNWR has been a success. We suggest further monitoring and population studies to continue to monitor the Blanding's turtle population at SNWR. Future research should look into sex differences, additional age classes, and a continued effort to find wildborn juveniles within SNWR.

We observed high survivorship for the 24 headstarted Blanding's turtles tracked in this study. Congdon et al. (1993) determined that for Blanding's turtle populations to be stable, survivorship $>70 \%$ for juveniles $1-13$ years old is needed with a cohort generation time of 37 years. The survival estimates for the headstarted Blanding's turtles thus far in this study are within the range described by Congdon et al. (1993) if $\geq 2$ of the headstarted Blanding's turtles that we lost signals for survived (15 surviving turtles, 8 transmitter losses, 1 mortality). An unpublished study reported that a release of headstarted turtles in SNWR in 2012 suffered mortality $>50 \%$, with $25 \%$ of the mortality occurring within 2 weeks after release due to raccoon predation (A. M. Cleary, affiliation, personal communication). Release site locations were changed for this study as a result, and survivability of headstarted turtles increased. A balanced percentage of males, females, and juveniles should be found in healthy populations of Blanding's turtles (Valentine National Wildlife Refuge, NE, USA; Bury and Germano 2003). Because trapping and bycatch attempts (volunteer, SNWR staff, University of Michigan-Flint student search efforts 2008-2015) at SNWR have captured no wild juveniles of this species thus far (M. D. Starking-Szymanski, University of Michigan-Flint, unpublished data), headstarting is likely required for the SNWR population to have any chance of persisting in the long term.

The headstarted Blanding's turtles in this study moved an average of $1,005 \mathrm{~m}$ in straight-line distance between relocations for the duration of the study. Turtles did not move differently between their first and second active seasons, similar to findings from Anthonysamy et al. (2013) where adult and juvenile Blanding's turtles did not differ in distances moved between years. We saw wide variability of cumulative and weekly movement distances in the headstarted Blanding's turtles $(568.8-2,972.3 \mathrm{~m})$ over the duration of the study. In Maine, Blanding's turtles migrate long distances between wetland types because of differences in seasonal needs (Beaudry et al. 2009). Adult Blanding's turtles studied by Congdon et al. (2011) in Michigan moved a variety of distances, primarily for mating and nesting; most nests were within $1,000 \mathrm{~m}$ away from the gravid females' resident wetland. This is similar to the $1,005-\mathrm{m}$ mean distance moved by the headstarted Blanding's turtles in our study, and similarities might link to nesting dispersal distances.

For the first 18 months after release, turtle distances from release site to center home range were not different among release groups. We believe this shows the importance of release locations for headstarted turtles; turtles will remain near release sites. In the GWR analysis, distance from the release site was affected by the release site. This shows cumulatively how even though the mean center home range did not vary, home ranges were somewhat larger for some release sites presumably due to unfavorable land cover. Congdon et al. (2011) reported that $75 \%$ of adult Blanding's turtles stayed in the same resident wetland over a 19-year study, showing that Blanding's turtles have site fidelity. Newton and Herman (2009) also reported that Blanding's turtles have site fidelity, and turtles raised in captivity overwintered with wild Blanding's turtles, indicating that headstarted turtles used the same habitats as their wild counterparts.

We used the MCP method because one of the goals of this study was to compare headstart home ranges to the home ranges of their wild counterparts. Recent methods like Brownian bridges or local convex hull $(\mathrm{LoCoH})$ consider 


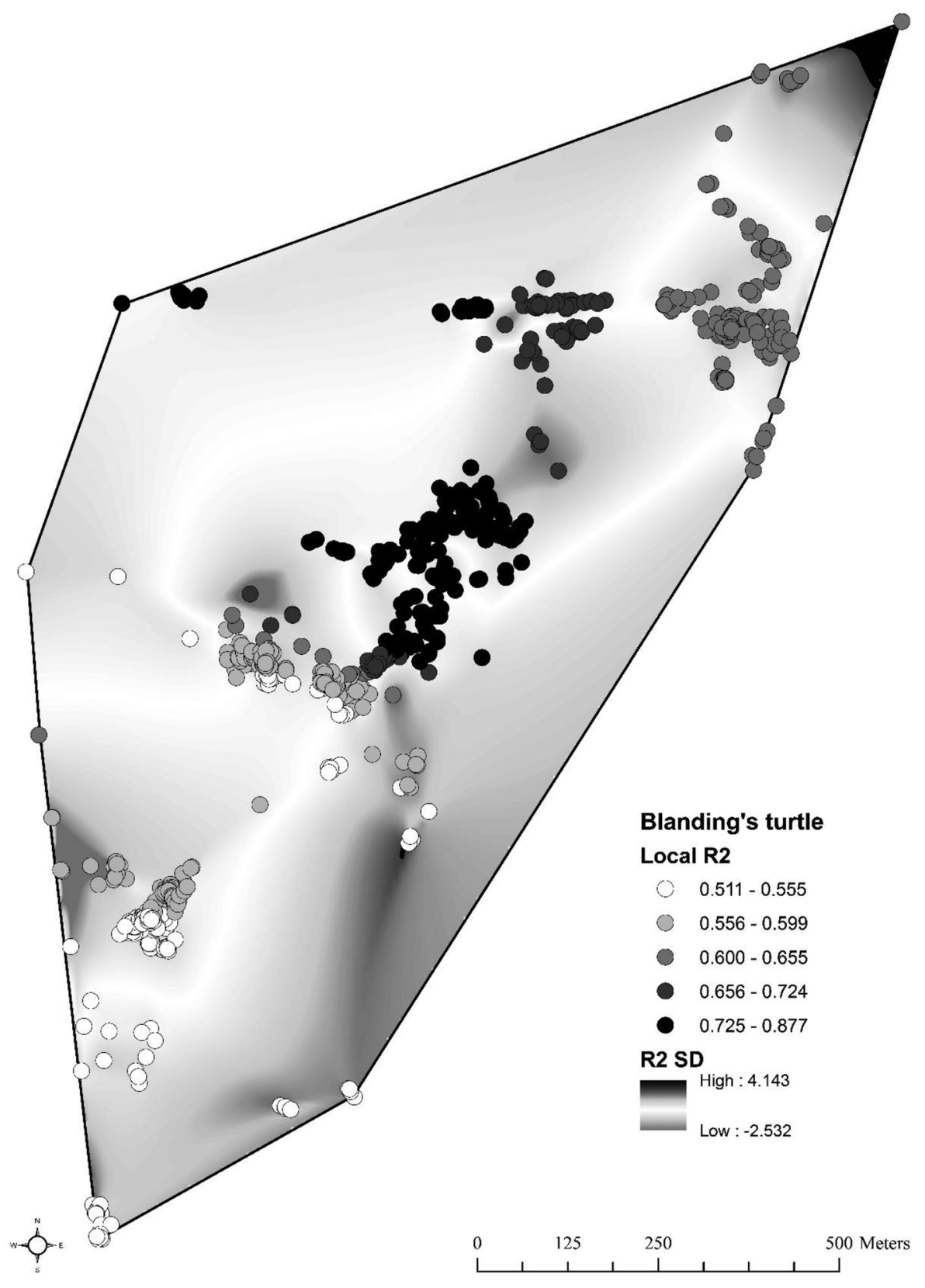

Figure 5. The geographically weighted regression (GWR) adjusted local $R^{2}$ values at each Blanding's turtle point Shiawassee National Wildlife Refuge, Michigan, USA, June 2014 to November 2015. The independent variables (IV) used are water depth, water temperature, cattails, muskrat downed or disturbed cattails, buttonbush, and release groups. Points represent local $R^{2}$ values. Black points are areas where the IV predict the distance away from release site well (higher $R^{2}$ value) with the highest $R^{2}$ value at 0.877 , white points are less explained by the IV (lower $R^{2}$ value) with the lowest $R^{2}$ at 0.511 . Additional factors may be responsible for headstarted Blanding's turtle movement at locations with lower values within Shiawassee National Wildlife Refuge. We show $R^{2}$ standard deviations from high to low within the turtle population range.

time and space when computing animal home ranges, and are more accurate at representing space use of animals (Getz et al. 2007, Horne et al. 2007). These methods, however, required 1 week between relocations, which we were unable to achieve in our study. Several studies have reported on Blanding's turtles home ranges using the MCP method, even though MCP can be an over estimation of home range size (Table 4). Additionally, Row and Blouin-Demers (2006) reported kernel home ranges to be unreliable home range estimators for herpetofauna because they overestimate area and because selection of a smoothing factor is subjective. The measured MCP home ranges for the headstarted Blanding's turtles indicated a difference between release groups; however, with no difference between years. Release group $1 \mathrm{had}$ the largest mean group home range $(2.9 \mathrm{ha})$ and release group 4 had the smallest mean group home range $(0.4 \mathrm{ha})$. We can infer from this that the differences in these home range sizes were due to the variation of microhabitats found at the release sites. The mean MCP home range of Blanding's turtles in our study was 2.8 ha, and MCP home ranges of juvenile Blanding's turtles measured in other studies ranged from 1.3 ha to $12.8 \mathrm{ha}$ (Piepgras and Lang 
Table 4. Mean home range size for Blanding's turtles across studies. We specify adult males (M), adult non-gravid females (NGF), adult gravid females (GF), and juveniles $(\mathrm{J})$ and present sample size $(n)$ in parentheses. We also show the reference, study location, and method $(\operatorname{minimum}$ convex polygon $[\mathrm{MCP}]$ or fixed kernel) used to calculate home range size.

\begin{tabular}{|c|c|c|c|c|c|}
\hline Reference & Location & Method & $n$ & $\bar{x}$ (ha) & SE \\
\hline \multirow[t]{3}{*}{ Anthonysamy et al. (2013) ${ }^{a}$} & IL, USA & $\mathrm{MCP}$ & M (4) & 22.9 & \pm 0.92 \\
\hline & & & $F(9)$ & 17.9 & \pm 5.2 \\
\hline & & & $\mathrm{J}(4)$ & 5.4 & \pm 0.92 \\
\hline \multirow[t]{2}{*}{ Edge et al. (2010) } & ON, Canada & MCP & $M(5)$ & 57.1 & \pm 15.3 \\
\hline & & & $\mathrm{F}(16)$ & 61.2 & \pm 30.4 \\
\hline Fortin et al. (2012) & QC, Canada & MCP & Pooled (44) & 29.7 & \pm 32.3 \\
\hline \multirow[t]{2}{*}{ Grgurovic and Sievert (2005) } & MA, USA & 95\% fixed kernel & $\mathrm{M}(14)$ & 27.5 & \pm 0.10 \\
\hline & & & $\mathrm{F}(27)$ & 19.9 & \pm 0.07 \\
\hline \multirow[t]{2}{*}{ Hamernick (2000) ${ }^{a}$} & MN, USA & $\mathrm{MCP}$ & $\mathrm{M}(8)$ & 94.92 & \pm 19.31 \\
\hline & & & $\mathrm{F}(16)$ & 60.75 & \pm 3.05 \\
\hline \multirow[t]{3}{*}{ Innes et al. $(2008)^{b}$} & NH, USA & MCP & $M(4)$ & 3.7 & \\
\hline & & & $\mathrm{F}(6)$ & 3.35 & \\
\hline & & & $\mathrm{J}(1)$ & 3.2 & \\
\hline \multirow[t]{4}{*}{ Kasuga $(2007)^{a}$} & IL, USA & $\mathrm{MCP}$ & $M(5)$ & 32.53 & \pm 7.45 \\
\hline & & & NGF (9) & 47.64 & \pm 3.85 \\
\hline & & & GF (2) & 29.26 & \pm 2.48 \\
\hline & & & $\mathrm{J}(1)$ & 1.27 & \\
\hline \multirow{3}{*}{ Millar and Blouin-Demers (2011) } & ON, Canada & MCP & M (20) & 8.5 & \pm 1.7 \\
\hline & & & NGF (5) & 7.3 & \pm 3.2 \\
\hline & & & GF (12) & 20.3 & \pm 3.5 \\
\hline \multirow[t]{3}{*}{ Piepgras and Lang (2000) } & MN, USA & $\mathrm{MCP}$ & M (6) & 7.8 & \pm 0.61 \\
\hline & & & F (13) & 7.8 & \pm 0.34 \\
\hline & & & $\mathrm{J}(6)$ & 5.9 & \pm 0.40 \\
\hline \multirow{2}{*}{ Schuler and Thiel (2008) } & WI, USA & MCP & $M(9)$ & 26.1 & \\
\hline & & & F (9) & 20.7 & \\
\hline This study & MI, USA & MCP & $\mathrm{J}(24)$ & 2.80 & \pm 0.95 \\
\hline
\end{tabular}

${ }^{a}$ Other methods along with MCP were used in study, such a kernel density.

${ }^{\mathrm{b}}$ Median values used.

2000, Kasuga 2007, Innes et al. 2008, Anthonysamy et al. 2013). Juvenile Blanding's turtle home ranges are smaller on average than adult Blanding's turtles; previous research supports this in studies with wild-born juveniles (Table 4). More broadly, our finding is additional evidence that the headstart program is not interfering with the juvenile turtles' behaviors and movements in the SNWR. However, we were unable to find and compare the headstarted turtles to wild-born Blanding's turtles at SNWR because no wild-born Blanding's turtles have been captured or observed in SNWR over multiple years of sampling, thus leading to the headstart program.

We found microhabitat features to be an important predictor of habitat use of headstarted Blanding's turtles. Headstarted Blanding's turtles at SNWR avoided open water, which is similar to studies on adults (Hamernick 2000, Millar and Blouin-Demers 2011). Millar and Blouin-Demers (2012) reported a low density of open water fit in a habitat suitability model for Blanding's turtle. We found that headstarted Blanding's turtles also avoided willows and lowland forested wetlands. When we released group 1 turtles in open water, they used lowland forested wetlands. Within the lowland forest, we found these turtles most often near buttonbush or cattail stands. Hartwig and Kiviat (2007) reported that subadult and adult Blanding's turtles were associated with buttonbush in New York, USA. Headstarted Blanding's turtles used cattails and muskrat dens in a greater proportion than their availability. We released groups 2 and 4 in cattails; they had the shortest measured straight-line distance to mean center home range among release groups. We found headstarted Blanding's turtles basking on top of muskrat dens (Starking-Szymanski 2016), and tracked to muskrat dens where turtles seemed to be residing inside or under the dens. Previous data within SNWR reported that Blanding's turtles prefer emergent wetlands that contain cattails and muskrat dens (A. M. Cleary, unpublished data). Contrastingly, other research has not documented this, but other studies have not separated and analyzed land cover types separately as we have.

The results of GWR analysis showed improvements over the OLS model, and may be the first attempt at using this method for examining contributing factors on turtle travel distances from release sites. The independent variables in the GWR model (water depth and temperature, duckweed, cattails, muskrat dens and fields, buttonbush, and release sites) were able to explain $75.5 \%$ of the variation in distance from release sites by headstarted Blanding's turtles. Taken together, the land cover types at the release sites and subsequent relocations influence the distances that headstarted Blanding's turtles will travel away from their release site. Fortin et al. (2012) used logistic regression and reported that landscape composition had a weak impact on movement and home range size differences of Blanding's turtles. They reasoned that low variability of land uses within the home ranges diminished any explanatory power. We predicted distances of headstarted Blanding's turtles from release sites and compared these to home ranges and space use using microhabitat factors (dominant vegetation within a quadrat at each turtle relocation), instead of home range size and broad wetland categories. This gave us the ability to analyze 
the influences of variables on movement with a local geographic regression approach on animal space use.

By releasing headstarted Blanding's turtles at 4 different release sites with varying microhabitat features, measuring habitat factors at relocations, and then examining how these habitat factors related to distance from release site, we tested for the biological importance of habitats as suggested by Alldredge and Griswold (2006). In our study, we randomly released turtles at release site 1 into open water, with the only vegetation nearby being willows; headstarted Blanding's turtles used open water and willow less than available. Five out of 6 turtles from release site 1 left the site and never returned. This behavior does not match juvenile movement patterns from other studies. Juvenile Blanding's turtles from another study traveled less often than adults and $>60 \%$ of them never moved out or between their resident wetland (Piepgrass and Lang 2000). Headstarted turtles released at site 1 had a high rate of movement out of the original wetland, which could be because the cover type at the release site was open water. Headstarted turtles released at this site had to cross a road, which is a behavior adult and juvenile Blanding's turtles often avoid (Proulx et al. 2014), and their aversion to open water was likely an influencing factor. Edge et al. (2010) reported that fine-scale habitat preference detection may not be possible in high-quality landscapes, but we were able to detect a preference of certain land cover types even though SNWR is a complex of wetlands. Juvenile Blanding's turtles released in preferred land cover types had smaller home range sizes overall. Release locations for headstarted Blanding's turtles benefit the turtles most when they are in preferred land cover types, and it is possible to use microhabitat variables to predict turtle movement.

\section{MANAGEMENT IMPLICATIONS}

Given the results of our study, biologists should release headstarted Blanding's turtles in their preferred habitat of dense cattails with plenty of muskrat dens for basking and refuge if available. We found that juvenile Blanding's turtles could be headstarted to 18 months of age while still behaving similarly to their wild-born counterparts. Using spatially explicit models helped to increase the predictive power of space use by these headstarted Blanding's turtles. Researchers should continue to use these models to study headstart program success because of the late maturity and longevity of Blanding's turtles. As technology increases and transmitter weight decreases, newer methods to depict home ranges of turtles will improve. By releasing turtles in a location with microhabitats suited to their needs, biologists can minimize the dangers from predation and improve management techniques that increase and stabilize populations of turtles, the most threatened vertebrate group in the world (Buhlmann et al. 2009).

\section{ACKNOWLEDGMENTS}

We thank the USFWS, Michigan Department of Natural Resources, S. F. Kahl, E. M. Dunton, and other employees at Shiawassee National Wildlife Refuge for all their support and assistance. We also thank T. H. Kaufman for taking orthophotos of the study area for this project. We thank J. A.
Jundt and other employees at DZS for help with this research. We thank M. J. Boyer, E. S. Kiser, M. K. Schott, and H. M. Smith for field assistance. We thank the turtle crew who went above and beyond the call of duty in helping with this research and whom without this project could not have happened: W. D. Gibala, M. J. Smith, S. R. Davis, K. M. B. Hughes, J. L. Taylor, and M. M. Warda. We thank L. W. Atherton, A. C. Louis, D. P. Viele, and others from University of Michigan-Flint for support and assistance. We thank M. Goode and 2 anonymous reviewers for providing useful comments on an earlier version of this manuscript. We thank the Biology Department (Graduate Student Research Fund and Murchie Memorial Research Fund), College of Arts and Sciences, E. A. Kingsley and Office of Research and Sponsored Programs ("Doc" Studier Research Memorial Fund and Undergraduate Research Opportunity Program), Office of Graduate Programs (Graduate Student Research Assistantship), and the Fran Frazier Student Travel Scholarship for supporting this study.

\section{LITERATURE CITED}

Alldredge, J. R., and J. Griswold. 2006. Design and analysis of resource selection studies for categorical resource variables. Journal of Wildlife Management 70:337-346.

Anthonysamy, W. J. B., M. J. Dreslik, and C. A. Phillips. 2013. Disruptive influences of drought on the activity of a freshwater turtle. American Midland Naturalist 169:322-335.

Barker, R., and D. J. King. 2012. Blanding's turtle (Emydoidea blandingii) potential habitat mapping using aerial orthophotographic imagery and object based classification. Remote Sensing 4:194-219.

Bates, D., M. Maechler, B. Bolker, and S. Walker. 2015. Fitting linear mixedeffects models using lme4. Journal of Statistical Software 67(1):1-48.

Beaudry, F., P. G. DeMaynadier, and M. L. Hunter Jr. 2009. Seasonally dynamic habitat use by Spotted (Clemmys guttata) and Blanding's turtles (Emydoidea blandingii) in Maine. Journal of Herpetology 43:636-645.

Buhlmann, K. A., T. S. B. Akre, J. B. Iverson, D. Karapatakis, R. A. Mittermeier, A. Georges, A. G. J. Rhodin, P. P. Van Dijk, and J. W. Gibbons. 2009. A global analysis of tortoise and freshwater turtle distributions with identification of priority conservation areas. Chelonian Conservation and Biology 8:116-149.

Burke, R. L., C. M. Schneider, and M. T. Dolinger, 2005. Cues used by raccoons to find turtle nests: Effects of flags, human scent, and diamondbacked terrapin sign. Journal of Herpetology 39:312-315.

Burt, J., G. Barber, and D. Rigby. 2009. Elementary statistics for geographers (third edition). Guilford Press, New York, New York, USA.

Bury, R. B., and D. J. Germano. 2003. Differences in habitat use by Blanding's turtles, Emydoidea blandingii, and painted turtles, Chysemys picta, in the Nebraska Sandhills. American Midland Naturalist 149:241-244.

Byers, C. R., R. K. Steinhorst, and P. Krausman. 1984. Clarification of a technique for analysis of utilization-availability data. Journal of Wildlife Management 48:1050-1053.

Cagle, F. R. 1939. A system of marking turtles for future identification. Copeia 3:170-173.

Charlton, M., and M. S. Fotheringham. 2009. Geographically weighted regression white paper. Science Foundation Ireland, Dublin, Ireland.

Cohen, J. E. 1988. Statistical power analysis for the behavioral sciences. Lawrence Erlbaum Associates, Hillsdale, New Jersey, USA.

Congdon, J., A. Dunham, and R. Sels. 1993. Delayed sexual maturity and demographics of Blanding turtles (Emydoidea-blandingii)-implications for conservation and management of long-lived organisms. Conservation Biology 7:826-833.

Congdon, J. D., O. M. Kinney, and R. D. Nagle. 2011. Spatial ecology and core-area protection of Blanding's turtle (Emydoidea blandingii). Canadian Journal of Zoology 89:1098-1106.

Dormann, C. F., J. M. McPherson, M. B. Araújo, R. Bivand, J. Bolliger, G. Carl, R. G. Davies, A. Hirzel, W. Jetz, W. D. Kissling, I. Kühn, R. 
Ohlemüller, P. R. Peres-Neto, B. Reineking, B. Schröder, F. M. Schurr, and R. Wilson. 2007. Methods to account for spatial autocorrelation in the analysis of species distributional data: A review. Ecography 30:609-628.

Edge, C. B., B. D. Steinberg, R. J. Brooks, and J. D. Litzgus. 2010. Habitat selection by Blanding's turtles (Emydoidea blandingii) in a relatively pristine landscape. Écoscience 17:90-99.

Escobar, R. A., E. Besier, and W. K. Hayes. 2010. Evaluating headstarting as a management tool: post-release success of green iguanas (Iguana iguana) in Costa Rica. International Journal of Biodiversity and Conservation 2:204-214.

Forsythe, P., B. Flitz, and S. J. Mullin. 2004. Radio telemetry and postemergent habitat selection of neonate box turtles (Emydidae: Terrapene carolina) in Central Illinois. Herpetological Review 35:33-335.

Fotheringham, A. 2009. Geographically weighted regression. Pages 243-254 in A. S. Fotheringham, and P. A. Rogerson, editors. The SAGE handbook of spatial analysis. SAGE Publications, London, England.

Fotheringham, A. S., M. E. Charlton, and C. Brunsdon. 2002. Geographically weighted regression: the analysis of spatially varying relationships. Wiley, London, United Kingdom.

Fotheringham, A. S., C. Brunsdon, and M. E. Charlton. 2000. Quantitative geography: perspectives on spatial data analysis. SAGE Publications, London, England.

Fotheringham, A. S., C. Brunsdon, and M. E. Charlton. 1998. Geographically weighted regression: a natural evolution of the expansion method for spatial data analysis. Environmental Planning A 30:1905-1927.

Fortin, G., G. Blouin-Demers, and Y. Dubois. 2012. Landscape composition weakly affects home range size in Blanding's turtles (Emydoidea blandingii). Écoscience 19:191-197.

Fraser, D. J. 2008. How well can captive breeding programs conserve biodiversity? A review of salmonids. Evolutionary Applications 1:535-586.

Getz, W. M., S. Fortmann-Roe, P. C. Cross, A. J. Lyons, S. J. Ryan, and C. C. Wilmers. 2007. LoCoH: nonparameteric kernel methods for constructing home ranges and utilization distributions. PLoS ONE 2:e207.

Grgurovic, M., and P. R. Sievert. 2005. Movement patterns of Blanding's turtles (Emydoidea blandingii) in the suburban landscape of eastern Massachusetts. Urban Ecosystems 8:203-213.

Gutzke, W. H. N., and G. C. Packard. 1987. The influence of temperature on eggs and hatchlings of Blanding's turtles, Emydoidea blandingii. Journal of Herpetology 21(2):161-163.

Hamernick, M. G. 2000. Home ranges and habitat selection of Blanding's turtles (Emydoidea blandingii) at the Weaver Dunes, Minnesota. Final report submitted to the Nongame Wildlife Program, Minnesota Department of Natural Resources, St. Paul, Minnesota, USA.

Hartwig, T. S., and E. Kiviat. 2007. Microhabitat association of Blanding's turtles in natural and constructed wetlands in southeastern New York. Journal of Wildlife Management 71:576-582.

Heppell, S. S., L. B. Crowder, and D. T. Crouse. 1996. Models to evaluate headstarting as a management tool for long-lived turtles. Ecological Applications 6:556-565.

Horne, J. S., E. O. Garton, S. M. Krone, and J. S. Lewis. 2007. Analyzing animal movements using Brownian bridges. Ecology 88:2354-2363.

Innes, R. J., K. J. Babbitt, and J. J. Kanter. 2008. Home range and movement of Blanding's turtles (Emydoidea blandingii) in New Hampshire. Northeastern Naturalist 15:431-444.

Jaeger, C. P., and V. A. Cobb. 2012. Comparative spatial ecologies of female painted turtles (Chrysemys picta) and red-eared sliders (Trachemys scripta) at Reelfoot Lake, Tennessee. Chelonian Conservation and Biology 11:59-67.

Jones, M. T., and P. R. Sievert. 2012. Elevated mortality of hatchling Blanding's turtles in residential landscapes. Herpetological Conservation and Biology 7:89-94.

Kasuga, L. M. C. 2007. Small and large-scale landscape approaches for conservation of the imperiled Blanding's turtle, Emys blandingii. Thesis, Iowa State University, Ames, USA.

Kimsey, M. J. Jr., J. Moore, and P. McDaniel. 2008. A geographically weighted regression analysis of Douglas-fir site index in north central Idaho. Forest Science 54:356-366.

Legendre, P. 1993. Spatial autocorrelation: trouble or new paradigm? Ecology 74:1659-1673.

Lüdecke D. 2018. sjstats: statistical functions for regression models. $\mathrm{R}$ package version 0.14.1. https://CRAN.R-project.org/package=sjstats. Accessed 6 Feb 2018.
Maktav, D., F. Sunar, D. Yalin, and E. Aslan. 2000. Monitoring loggerhead sea turtle (Caretta caretta) nests in turkey using GIS. Coastal Management 28:123-132.

McNew, L. B., A. J. Gregory, and B. K. Sandercock. 2013. Spatial heterogeneity in habitat selection: nest site selection by greater prairiechickens. Journal of Wildlife Management 77:791-801.

Mignet, F., T. Gendre, D. Reudet, F. Malgoire, M. Cheylan, and A. Besnard. 2014. Short-term evaluation of the success of a reintroduction program of the European pond turtle: the contribution of space-use modeling. Chelonian Conservation and Biology 13:72-80.

Millar, C. S., and G. Blouin-Demers. 2012. Habitat suitability modelling for species at risk is sensitive to algorithm and scale: a case study of Blanding's turtle, Emydoidea blandingii, in Ontario, Canada. Journal for Nature Conservation 20:18-29.

Millar, C. S., and G. Blouin-Demers. 2011. Spatial ecology and seasonal activity of Blanding's turtles (Emydoidea blandingii) in Ontario, Canada. Journal of Herpetology 45:370-378.

Millspaugh, J. J., and J. M. Marzluff. 2001. Radio tracking and animal populations. Academic Press, San Diego, USA.

Mitrus, S. 2008. The headstarting technique is an ineffective method for conservation of the European pond turtle-elasticity analysis. Ecological Questions 10:51-55.

Neu, C. W., C. R. Byers, and J. M. Peek. 1974. A technique for analysis of utilization-availability data. Journal of Wildlife Management 38: 541-545.

Newton, E. J., and T. B. Herman. 2009. Habitat, movements, and behavior of overwintering Blanding's turtles (Emydoidea blandingii) in Nova Scotia. Canadian Journal Of Zoology 87:299-309.

Pearl, R., and J. Miner. 1935. Experimental studies on the duration of life. XIV. The comparative mortality of certain lower organisms. Quarterly Review of Biology 10:60-79.

Peel, M. C., B. L. Finlayson, and T. A. McMahon. 2007. Updated world map of the Köppen-Geiger climate classification. Hydrology and Earth System Sciences Discussions 4:439-473.

Piepgras, S. A., and J. W. Lang. 2000. Spatial ecology of Blanding's turtle in central Minnesota. Chelonian Conservation and Biology 3:589-601.

Proulx, C. L., G. Fortin, and G. Blouin-Demers. 2014. Blanding's turtles (Emydoidea blandingii) avoid crossing unpaved and paved roads. Journal of Herpetology 48:267-271.

R Core Team. 2016. R: a language and environment for statistical computing. R Foundation for Statistical Computing, Vienna, Austria.

Reading, R. P., B. Miller, and D. Shepherdson. 2013. The value of enrichment to reintroduction success. Zoo Biology 32:332-341.

Rosenshein, L., and L. Scott. 2011. Spatial statistics: best practices. ESRI Users Conference 2011, San Diego, California, USA.

Row, J. R., and G. Blouin-Demers. 2006. Kernels are not accurate estimators of home-range size for herpetofauna. Copeia 4:797-802.

Ruane, S., S. A. Dinkelacker, and J. B. Iverson. 2008. Demographic and reproductive traits of Blanding's turtles, Emydoidea blandingii, at the western edge of the species' range. Copeia 4:771-779.

Schuler, M., and R. Thiel. 2008. Annual vs. multiple-year home range sizes of individual Blanding's turtles, Emydoidea blandingii, in central Wisconsin. Canadian Field-Naturalist 122:61-64.

Spencer, D. G., J. Leach, N. M. Fuller, and W. F. Hartwig. 2001. Shiawassee National Wildlife Refuge Comprehensive Conservation Plan. U.S. Fish and Wildlife Service, Washington, D.C., USA.

Starking-Szymanski, M. D. 2016. Investigation of headstarted Blanding's turtles (Emydoidea blandingii) in Shiawassee National Wildlife Refuge, Saginaw, MI. Thesis, University of Michigan-Flint, Flint, USA.

Vander Haegen, W. M., S. L. Clark, K. M. Perillo, D. P. Anderson, and H. L. Allen. 2009. Survival and causes of mortality of head-started western pond turtles on Pierce National Wildlife Refuge, Washington. Journal of Wildlife Management 73:1402-1406.

World Wildlife Fund. 2016. Living Planet Report 2016. Risk and resilience in a new era. WWF International, Gland, Switzerland.

Zhao, F., and N. Park. 2004. Using geographically weighted regression models to estimate annual average daily traffic. Transportation Record: Journal of the Transportation Research Board 1879:99-107.

Associate Editor: Matt Goode. 